УДК 101.1:316.334.56(47+57)

\title{
СЕМИОТИЧЕСКАЯ ИНВЕНТАРИЗАЦИЯ ГОРОДА И ПРОБЛЕМА ИНТЕНСИВНОГО ПРОСТРАНСТВЕННОГО РАЗВИТИЯ
}

\author{
Колодий Наталия Андреевна 1 , \\ kolna@tpu.ru \\ Баджио Рудольфо 1 , \\ rodolfo.baggio@unibocconi.it \\ Гончарова Наталья Александровна ${ }^{1}$, \\ natg@tpu.ru \\ Чайка Юлия Александровна 1 , \\ chayka@tpu.ru \\ Иванова Вера Степановна ${ }^{2}$, \\ vcsoc@rambler.ru \\ ${ }^{1}$ Национальный исследовательский Томский политехнический университет, \\ Россия, 634050, г. Томск, пр. Ленина, 30 \\ ${ }^{2}$ Национальный исследовательский Томский государственный университет, \\ Россия, 634050, г. Томск, пр. Ленина, 36
}

Колодий Наталия Андреевна, доктор философских наук, профессор Школы базовой инженерной подготовки Национального исследовательского Томского политехнического университета.

Баджио Рудольфо, PhD, профессор Школы базовой инженерной подготовки Национального исследовательского Томского политехнического университета.

Гончарова Наталья Александровна, кандидат экономических наук, доцент Школы базовой инженерной подготовки Национального исследовательского Томского политехнического университета.

Чайка Юлия Александровна, старший преподаватель Школы базовой инженерной подготовки Национального исследовательского Томского политехнического университета.

Иванова Вера Степановна, кандидат философских наук, доцент Философского факультета Национального исследовательского Томского государственного университета.

Влияние, которое оказывают современные горожане на пространственное развитие городов, заставляет и градопроектировщиков, и тех, кто реализует различные городские проекты, обращать внимание на те языки описания города, которые создают доминирующий образ уникального пространства и территории. Это воздействие может сделать пространственное развитие гармоничным и устойчивым, а может препятствовать реализации любого городского проекта. В статье, посвященной анализу языков описания города, обсуждается ряд проблем, связанных с пониманием того, при каких условиях языки описания города способствуют формированию идентичности города и его аутентичному пространственному развитию, а при каких создают неоднозначные противоречивые образы. Методы. Методологической основой являлся структурно-семиотический подход, поскольку он выстраивает систему анализа города как текста, и города, как текстопорождающего механизма, смыслосоздающей системы. В качестве концептуального ориентира также использовалась концепция городского воображаемого (А. Блум, К. Линч, М. Де Серто), позволившая рассматривать этот феномен как продукт восприятия городской реальности, оформленный в виде различных интерпретативных схем и текстов. Семиотическая инвентаризация, связанная с пространственной систе- 
мой современного города, нужна для того, чтобы понять: как будет «производиться» новый символический порядок города, его новая символическая вселенная. Результаты исследования, представленные в статье, основаны на интерпретации ментальных карт, диджитал-феноменов, что позволило воссоздать контуры визуального образа сибирского города (как целостного образования) с определённой системой кодирования смыслов. Выводы. Междисциплинарные городские исследования, интенсификация которых связана часто с попытками трансформировать город, создают объёмные описания культурного ландшафта города, где структурообразующим будет образ, не противоречащий сложившейся системе городского семиозиса.

Ключевые слова: Городской текст, локальный текст, визуальные исследования, семиотический подход, культурно-обусловленное проектирование, язык описания города.

Сегодня возможны три варианта интенсивного пространственного развития и модернизации городов. Первый путь - абсолютно осознанный, воплощённый в определённых сценариях городского развития, построенных на так называемых больших стратегиях: создание эффективно-функционирующих агломераций, кластеров; формирование инновационных технологических коридоров, распространение опыта умных городов, ориентированных на человека (Human Smart cities) и т. п. [1]. В последнее время на самых разных уровнях происходит отказ от глобальных стратегий в сторону гибкости реагирования, подвижных альянсов городов и поселений, пригородов на основе общности интересов. Это смещение ориентиров делает плановое развитие городов, главным образом городов-миллионников, противоречивым процессом, игнорирующим уникальность городов [2].

Второй путь - любой город может переживать активную фазу обсуждения особенностей пространственного развития, а потом и градостроительства в силу событийного маркетинга («Мега-всё: события, проекты, города»). В России чаще всего это связано с организацией и проведением мегасобытий, например, спортивных [3]. Особые условия обсуждения, а потом и развития складывались в российских городах, где проходил Чемпионат мира по футболу 2018 г., Универсиада 2019 г., планировалось проведение ЭКСПО 2020 (Казань и Сочи, Красноярск и Екатеринбург). Создавая новые спортивные и иные объекты, градостроители вынужденно проявляют внимание к сохранению пространства, связанного с историческим наследием города, и строже осуществляют «зелёный» контроль над загрязнением почв, утилизацией отходов, осуществляя параллельно защиту культурного и биологического разнообразия [4]. Город выигрывает дважды, если это связано с целостностью подхода к пространственному развитию. Именно такой целостности в управлении этим процессом в российских условиях и не достаёт. Любые мегапроекты в России не единственный эффективный путь развития, нужна новая последовательная градостроительная политика, касающаяся всех регионов, основанная на полноценной «ревизии» города как сложной семиосферы.

И наконец, третий путь - это путь естественных трансформаций, основанный на органичной региональной идентичности, в становлении которой принимает активное участие научное, журналистское и даже властное сообщества, результатом чего становится качественный редевелопмент, основанный на ресимволизации, ребрендинге, репозиционировании города $[5,6]$. Именно такой редевелопмент формирует новые связи в городе, раскрывает потенциал места, оживляет городскую ткань, сохраняет «дух места», и одновременно увеличивает коммерческую ценность территории. Этот путь самый сложный, в России он, скорее, демонстрирует провалы, нежели успехи, но именно он интересует нас в первую очередь.

В рамках этого сценария импульсом к пространственному развитию могут стать и концепции «Большого города», «Большого университета», как, например, в Томске [7]. 
Императив «большого города» не означает актуализацию лозунга «назад к глобализации», но и не свидетельствует об отказе от локальности в современной России. Он означает более последовательную рефлексию над соотношением глобального/локального в пространственном развитии, введение в действие новых видов энергии горожан, синергию действий региональных элит. Определение «большой» таит в себе определённую многозначность. Есть какая-то очевидная инфантильность в этих претензиях на «Большой город» и «Большой университет». Томск как будто впервые осознал себя «большим», в противовес детскости, даже не юности; «умным»- в противовес традиционно развивающимся городам; сохраняющим аутентичность - в противовес гибридным формам. С одной стороны, использование этого слова в прямом позиционировании города снимает ряд претензий на столичность, доминирование в некоем региональном пространстве (когда-то существовали метафоры: «Томск - сибирские Афины», «культурная столица Сибири»). С другой стороны, усиливает трезвость в оценке возможностей занятия конкурентно выгодной позиции в глобальном мире. Этот новый императив предполагает смену позиций в оценке инструментов, способных превратить ресурсы города в новый тип социального капитала. Претензии на создание «большого города» означают отказ от провинциальности, догоняющих стратегий и продумывание модели релевантных действий элит и городских сообществ, не разрушающих локальное своеобразие. Именно этот последний тренд влечёт за собой спонтанную ресемиотизацию и ресимволизацию [8].

Таким образом, в первую очередь актуализируется структурно-семиотический подход к городу, поскольку он выстраивает систему анализа города как текста и города как текстопорождающего механизма, смыслосоздающей системы.

Методология выстраивается из принципов, подходов в системе визуальных исследований (тартусско-семиотическая школа), выявляющих особенности пространственной организации города, в которой отражается сложившийся механизм городского семиозиса. В качестве методологического ориентира использовалась концепция городского воображаемого (А. Блум, К. Линч, М. Де Серто), которая позволила, воспринимая городское воображаемое как продукт восприятия городской реальности, оформленный в виде «интерпретативных координатных сетей, согласно которым мы мыслим о чем-либо, оцениваем и решаемся на действие в местах» [9, с. 146] сформировать традицию понимания города. Также для нас актуальными были концептуальные рамки междисциплинарных урбанистических исследований, позволяющих благодаря синтезу методологических подходов проанализировать самопрезентацию города. В этих концептуальных рамках ключевую роль сыграли принципы конструктивистской парадигмы.

История изучения города как текста не раз восстанавливалась в деталях, схемах [10-24]. Нас будут интересовать те историко-урбанистические исследования, которые по сию пору формируют адекватную нашим целям и задачам исследовательскую оптику [25]. Инструментарий, используемый в подобных исследованиях, позволяет выявить алгоритм действий, задающих уникальность города, расшифровать смыслы, закодированные в любом явлении города. Такой инструментарий формируется благодаря трудам французских структуралистов и постструктуралистов $[13,26]$, исследованиям учеников тартусско-московской семиотической школы [27]. Усилиями этих авторов формируется визуальная семиотика, визуальные исследования города, визуальная антропология города $[28-31,9]$. Нас в этом отношении интересует и методология антропологической школы изучения локальных текстов постсоветских городов, которая развивалась не автономно, испытывая влияние со стороны исследований городского пространства в социологии города в XX в. (К. Линч, П. Бурдьё и др.). 
Обобщая результаты интервью, публикаций городских аналитиков, ментальных карт и диджитал-анализа, мы воссоздаём визуальную и вербальную модель собранного сибирского города как целостного образования, с определённой системой кодирования смыслов. Для более точного восприятия ряда явлений и феноменов города использовались методы натурного наблюдения.

\section{Город - это символическая вселенная}

Если использовать этот исследовательский подход для выявления особенностей города, то, разумеется, следует обратиться к языку семиотики, языку визуальных социологических исследований. Выводы исследований, осуществлённых в рамках такого подхода, становятся актуальными как для учёных, так и для градопроектировщиков. Самые значительные результаты, которыми могут воспользоваться градопроектировщики, возникают тогда, когда реконструируется своеобразный «каркас» образных представлений о городе, который каждый индивид, несомненно, простраивает для себя [25]. Именно благодаря такому каркасу в городских практиках реализуются определённые паттерны поведения людей. Структура города сложна, она, согласно Л. Вирту, рождает «мозаику социальных миров». При их взаимодействии и возникает проблема конфликта между репрезентацией пространства и пространствами репрезентаций [32, p. 48], которая выражается в том, что горожане вырабатывают собственное видение пространства города, создают образ своего адаптированного пространства, по-своему «понимают» особенности проектов, созданных профессионалами, и по-своему представляют реальные практики использования пространства. Этот образ часто приходит в противоречие с тем, что предлагается официальной культурой, градопроектировщиками. Так, например, возник конфликт интерпретаций в течение двух последних лет в Томске, когда Новособорную площадь одни трактуют как место некогда существовавшего Троицкого храма (сакральное пространство), в котором только и возможно строительство, если не храма, то часовни; другие - как популярное место досуга, третьи - как «место памяти», заслуживающее «охранной грамоты» навсегда. Западные коллеги не видят противоречий в сочетании реальных пространств города, в переплетении кодов и символов нескольких культурных традиций (в Томске это Новособорная площадь, площадь Ленина, удерживающая остатки священного входа в город и фрагменты советского города, хранящего память об основателях не столько города, сколько государства), российские исследователи усматривают в этом эклектику, от которой город должен освободиться.

Для западных и отечественных исследователей становится все более очевидным, что модернизация города должна происходить на базе выявленного культурного «каркаса», даже если речь идёт о воплощении концепции Human smart cities (умный город, ориентированный на человека). Культурный ландшафт сохраняет духовную и интеллектуальную энергию города, является драйвером пространственного развития и одновременно - барьером для него. Культурный ландшафт Томска (включая архитектурное измерение), к примеру, сохраняя сущность пространства с плотным культурно-насыщенным слоем, развивая генотип динамично-развивающегося университетского центра, и одновременно старинного сибирского города, должен на самом деле определять любые стратегии пространственного развития. Игнорирование этого приводит к неустойчивому и фрагментарному росту города.

Пока это неочевидно для всех акторов, участвующих в городских практиках нового обустройства Томска. Предшествующее обсуждение истории пространственного развития города, дискуссии последних лет отражают противоположность мнений по поводу 
«должного и реального» в культуре города; разное видение горожанами и властью ожидаемых путей ресимволизации. Причём это ментальное противостояние не позволяет объединить «инициативы сверху», смысл которых - «удерживать» уникальность города (например сайт, созданный, комитетом по сохранению исторического наследия департамента архитектуры и градостроительства администрации Томска) и «инициативы снизу». Образ специфического пути ресимволизации возникает в ходе обсуждения стратегий пространственного развития и в студенческой среде, где «немотствующее большинство» - студенты - представляют будущее города как вполне традиционное, типично-сибирское, а иностранные студенты, обучающиеся в городе, и вовсе видят будущее города как города русских парадоксов.

Ожидаемым, уютно-провинциальным предстаёт город в сетевых акциях, инициированных местным изданием «Томский Обзор». \#OldTownChallenge, \#OldTownChallengeTomsk и другие флэшмобы и перформансы в защиту памятников деревянного зодчества лишний раз доказывают, что «большим-глобальным-умным» его видят немногие.

Таким образом, к итогам (вненаучным) этого обсуждения следует отнести новую волну противостояния тех, кто хотел бы сохранить уникальность города - «заповедника деревянного зодчества», и тех, кто видит город современным, динамично развивающимся. Но в ходе этих дискуссий и реальной практики модернизации возникает опыт переопределения дискретных частей «недискретной» сущности города. Вопрошание в духе названия выставки «Томск, ты кто?» и в духе споров о границах исторического центра города становится активной интеллектуальной практикой города.

Переопределение коснулось смысла, который жители видели в Каменном мосте через реку Ушайку, созданным в 1916 г. по проекту томского архитектора К.К. Лыгина. Это место застраивалось благодаря разумным системам правил и архитектурных кодов, всегда воспринималось как абсолютная репрезентация «томскости». Современное обустройство набережной Ушайки привело к тому, что сегодня мост утратил свойства эстетически-выразительной и визуально-значимой доминанты этого пространства, что мгновенно отразилось в сознании горожан.

Каменный мост через Ушайку является одним из уникальных топосов города, содержащих ключ к пониманию исторической и сакральной топики (символические врата города). Внезапно, под воздействием разрушительной архитектурной интервенции, место стало не только визуально-агрессивным, но и требующим реанимации всей системы культурных кодов, задающим видение тех, кто город создаёт, и кто город просто видит; а также реконструкции топики города («топика понимается ... как метод и результат искусственной пространственной организации «места») [10, с. 71]. Ю.М. Лотман прав навсегда, утверждая, что «в свете трансформированного настоящего и прошлое меняет свой облик» [33, с. 385]. Проект, который реализовывался в течение пяти лет, как любые вновь возведённые объекты в историческом центре Томска, актуализирует не только проблему сохранения архитектурного наследия, ценного ландшафтного окружения, но и проблему выбора адекватной стратегии пространственного развития.

Топос, связанный с Каменным мостом, по-прежнему вызывает ассоциации исторического центра. Благодаря данному топосу, восприятие которого традиционно объединяется с представлением о том, как маркировалось в контексте городского семиозиса чужое пространство (пространство неукротимой природы, земля коренных жителей Сибири), как воспроизводится привычная программа символического освоения пространства, его превращения в «свое». 
Едва ли новые функции данного пространства (стать общественным пространством), которые предписаны ему современными градопроектировщиками, осуществят радикальное смещение в восприятии. Как подчёркивает историк архитектуры Л.Н. Вольская, в эпоху формирования основ планировочной системы города «масштабы застройки были соразмерны человеку» [34, с. 6]. В современных конструкциях на набережной Ушайки человек испытывает, находясь внизу каменной лестницы, гнетущее давление мощных объёмов гранита и бетона. Он не ощущает их соразмерными себе. Но думается, что привычное восприятие этого локуса выдержит испытание технологиями.

Порой очень парадоксальные тренды становятся тотальными, влияющими на процесс ревизии смысло- и градообразующей деятельности в городе, аудита сложившихся практик, а затем инвентаризации процессов ресемиотизации, дальнейшего приращения знаний о городе, трансформации мифоообраза города. Мифы прошлого или вновь возникающие мифы участвуют в обосновании философии открытости пространственных миров, выполняют компенсаторную функцию, восполняя утраченное ощущение идентичности, предлагают новый порядок означивания пространства, порой формируя особую констелляцию смыслов, заполняют смысловой вакуум. Как прежний, так и нынешний миф пробуждают энергию человеческого присутствия в этом пространстве, возникает какой-то новый горизонт смыслов. Так, например, чуть модернизированный миф Томского локального текста о святом Федоре Кузьмиче (императоре Александре I) задаёт парадигму изменения целого квартала в городе, но слабая историческая память горожан не даёт возможности выстроить какой-то новый тип отношений с указанным пространством.

В отношении российских городов следует подчеркнуть, что семиотическая инвентаризация нужна для того, чтобы понять: как будет «производиться» новый символический порядок города, новая символическая вселенная города. А анализ ресемиотизации позволит ответить на вопросы: будет ли актуальной новая региональная мифология, сибирскость, например; новая евроазиатскость, афинность, мифологема «город-университет», «большой город»? Кто глашатаи этого нового символического порядка? Станет ли реальностью более гармоничное территориальное развитие? Означает тот или иной «поворот», включая пространственный, возникновение проектов, призванных помочь городам построить свою обновлённую цивилизационную идентичность.

\section{Город versus локальный текст города}

В этом контексте принципиально иное значение приобретают городские исследования и те языки описания города, которые в связи с этим актуализируются. Особое внимание в таком контексте обращается и на стратегии исследований, которые предлагают в качестве итога сложные противоречивые выводы и разработанные на этой основе рекомендации. Например, стратегии изучения города как текста и текста о городе. Понятно, что одной только реализованной этой стратегии явно недостаточно для того, чтобы запустить процессы ресемиотизации. Но семиотические рамки, созданные некогда, задают параметры видения, являющиеся важными для градопроектировщиков, лиц, принимающих решения, экспертов, просто горожан. Надо заметить: для того, чтобы сформулировать основную идею проекта, представители голландского архитектурного бюро, например, в Томске провели ряд фокус-групп с населением города, выявляя ассоциации горожан, связанные с местом будущего проекта, анализируя особенности доминирующих архитектурных концепций в городе. Их предварительное исследование действительно базировалось на некоем тексте города, который они сконструировали [35]. 
Но какие особенности этого текста были учтены и прочитаны - покажет время. Действительно ли для этих архитекторов город представляет собой текст? Может быть, и правда: «идея города лучше постигается не столько его жителем, сколько сторонним наблюдателем» [36].

Архитектура, пожалуй, - это единственный текст, который читается ежедневно. И он требует не только прочтения, но и интерпретации - как от неофита, так и от продвинутого ученого и посвященного градостроителя. Простая прогулка по городу или виртуальное путешествие вынуждают любого «читателя», зрителя, будь то: классические фигуры фланёра, исследователя, обывателя, к прочтению и интерпретации. Любой из них создаёт своё описание города, вносит свой вклад в уже сложившийся текст. Конечно, это еще не полноценное понимание «текста, кода, знаков, синтаксиса, семантики пространства архитектуры» Ч. Дженкса. Но это важный и необходимый фрагмент будущего текста. Так постепенно создавались все известные тексты о городе, так постепенно исследователи провозгласили новый императив: «открытость процесса означивания» [13].

Даже базисные черты давно сложившейся архитектуры городов интерпретируются в процессе оживающего градостроения как бы заново. Архитектура Томска, изначально настолько своеобразная и определяемая особенностями рельефа (перепад высот может достигать 20, а то - 30 м), особенностями символического освоения пространства в Сибири, историей города (город как «охранительная сила» христианских традиций), при составлении очередного генерального плана интерпретируется по-разному: то как типично сибирская, то как уникальная, впитавшая в себя множество черт европейских архитектурных школ и стилей. Включение элементов веерной структуры в северо-восточной и юго-восточной частях города и формирование административного центра в южной части города затянулось на долгие годы, а «комплексный подход в организации системы благоустройства и озеленения, определив внешний зеленый пояс и внутреннее бульварное «кольцо», места городских парков и скверов, устройства набережных рек и протоков», до сих пор является обсуждаемым «теоретическим фундаментом томского градостроения〉 [37, с. 97].

В реальной жизни города, когда текст о городе и текст города существуют длительное время, они настолько противоречивы и калейдоскопичны, что любой из градопроектировщиков, любой из акторов городского поля приходит в недоумение по поводу принятия даже собственного решения. Дискуссии о создаваемых общественных пространствах в российских городах, например, в Томске, отчётливо это демонстрируют [38].

Собственно говоря, конфликт «между репрезентацией пространства и пространственной репрезентацией» [39] начал выявляться благодаря тому, что были отрефлексированы позиции путешественника и некоторых других пользователей городских пространств, в последнее время фокус исследовательской оптики сосредоточен на специфике видения так называемого Икара вуайериста [14]. Замечено, что сегодня создаётся такая архитектура, которая делает возможным «быстрый взгляд». Периферийные виды таких зданий смещают фокус зрения с физического объекта на субъект, который может «смотреть насквозь, вокруг, вниз, вверх и обозревать пространства, становясь частью иных пространственных взаимоотношений между субъектом и объектом» [40, с. 53].

Именно такую реконструкцию вуайеристского пространства Джеффри Кипнис охарактеризовал как «перформативный дискурс» [40]. С. Турома справедливо заметила, что Мишель де Серто удалось сформулировать самое существенное различие «между двумя когнитивными структурами, которые характеризуют артикуляции города: обоб- 
щающее видение тех, кто создает всеобъемлющие паноптические и теоретические конструкции, глядя на город с птичьего полета, и городские практики тех, кто анализирует город "снизу"» [19, с. 46]. Первых нарекли «вуайеристами», аналитиками городской ткани, «текстуры». Они создают репрезентацию для других [41].

Вторую группу в этом списке совершенно сознательно обозначили просто как обывателей, «тела которых, следуя всем изгибам городского «текста», записывают его, но неспособны его прочесть»; как тех, кто очарован «фрагментами траекторий и переменой мест» [14, p. 82]. Авторы этих текстов создают репрезентации для себя. Именно они репрезентируют вернакулярные районы и зоны города. Но каким парадоксальным предстаёт в современных проектах город. Достаточно внимательно посмотреть серию фотографий соборов, храмов, сделанных не профессионалами, а любителями.

Иногда кажется, что архитектор должен свою ключевую способность: видеть целостно, подпитывать какой-то энергией водной глади, лесных троп, для того, чтобы возникло нечто аутентичное, не противоречащее «духу места». Не случайно, М. Хайдеггер так тонко описал это хождение по тропе и путешествие по воде как процесс преуготовления к творчеству. Конечно, в мире есть практика обращения градопроектирповщиков к идеям тех, кто представляет феноменологический подход, позволяющий избежать редукционизма и элементаризма в архитектуре, но это, скорей, исключение, нежели правило. Именно этот подход ведёт к появлению архитектуры, которая не убивает «дух места», природу, историю, а вступает с ними в диалог. Проекты русских архитекторов в некоторых исторических центрах российских городов, например, в Казани, в Иркутске, воплощая архитектуру на стыке художественной инсталляции и традиционного архитектурного решения, создают совершенно новый «культурный ландшафт» (Иркутск с его идеями создания «исторических кварталов»). Будут ли выполнять такую функцию сегодняшние проекты в Томске - большой вопрос. А вот здания, построенные по проекту томского архитектора К.К. Лыгина (1854-1932 гг.) выполняли. Хотя и сейчас построенные здания этого архитектора трактуются как объекты, имеющие множество функций. Некоторые исследователи трактуют его архитектуру как проявление «бесстилевой архитектуры» и «кирпичного стиля»; другие - как систему, придающую своеобразие городу, создающую «метафизику ландшафта»; третьи - как начало архитектурного мейнстрима города [42].

В дополнение к традиционным урбанистическим исследованиям, которые дают ответ на этот вопрос, предлагая свою трактовку «текстуры города», в современных условиях появляется блок исследований, базирующихся на феноменологическом подходе. Эта совокупность исследований предлагает в качестве результатов такую систему образов и представлений, которая отражает и образ мира архитектора, и особенности картины мира людей, в интересах которых и создаются проекты. На становление этого процесса оказывают влияние и феноменологически мыслящие современные архитекторы, такие как С. Холл и П. Цумтор, и современные исследователи. Архитектура-знание-проект в таком ракурсе интерпретирует архитектуру Ю. Паласмаа [18]. Российские коллеги, например, московский архитектор Е.В. Асс, также проявляют интерес к этому подходу, удивительно точно описывая визуально трудно выразимые вещи - тактильные, слуховые и другие ощущения, которые волнуют его при реконструкции исторических объектов (например, Арсенала на территории Нижегородского кремля) [43]. Любопытно, что в исторической ретроспективе мы всегда можем обнаружить опыт тех архитекторов, кто интуитивно или рационально приходил к идее создания архитектуры на основе понимания сути жизненных миров людей, обитающих в этой местности. Подобную чуткость в ретроспективе проявлял томский архитектор В.Ф. Оржешко (1876 г. - после 1917 г.). Он, с 
одной стороны, уделял внимание к современным веяниям, включая внимание к драконьему стилю в норвежской деревянной архитектуре и его деталям (вписывая свой Дом с драконами в архитектурный ландшафт северного города), а с другой, рационально осмысливал потребности тех, кто был ожидаемым пользователем спроектированного им здания типографии «Сибирского товарищества печатного дела», кондитерской фабрики «Бронислав», формируя образ делового дома, задавая такую же атмосферу в городе в целом. А, например, А И. Лангер (1876 г. - после 1917 г.), еще один томский архитектор, настроенный более прагматически, применял иную стратегию, более конкретно интересуясь «гением места» $[44,45]$.

Если В.Ф. Оржешко трактовал сложно-организованную целостность города, территориально-знаково, создавая «надисторическую» архитектуру (по выражению Г. Ревзина «как пространственное искусство архитектура вообще не выглядит релевантной времени» [46]); то А.И. Лангер - темпорально-образно, реализуя свои проекты согласно своему исторически-организованному восприятию. Все объекты архитектурной реальности Томска, созданные выдающимися архитекторами, правда, до сих пор проанализированы лишь с точки зрения истории архитектуры, хотя так до сих пор доподлинно неизвестно, являлся ли В.Ф. Оржешко автором архитектурного проекта особняка И.А. Быстржицкого - Дома с драконами (ул. Красноармейская, 68). Впрочем, неполно расшифрован и смысл, символика драконов, которые украшают крышу и козырек над входом (7 стилизованных голов загадочного животного глядят на север, запад и юг).

Но так ли расшифровывают символику подобной архитектуры просто жители, туристы? Привычный набор распространённых определений: необычно, сказочно, загадочно, экзотично. Экзотизация городского пространства представляется и местным жителям, и туристам мощным трендом в создании архитектурного облика города. Действительно, подобных экзотически-причудливых строений «волшебного города» в Томске достаточно. Они представляют собой явную театрально-мифологическую часть пространства города, отличающегося, с одной стороны, нарочитой декоративностью, а с другой - удивительной практичностью архитектурных решений. Большая часть исследователей (В.Г. Залесов, И.Ю. Болтовская, Д.В. Прислонова) и подчёркивает этот прагматизм, проявившийся и в этом строении, и в целом - в возведении доходных домов томских купцов [47, с. 50].

Некоторые исследователи (О.В. Богданова, А.П. Герасимов) акцентуируют соединение эстетизма и практицизма, обусловленного характером полученного образования архитекторов и инженеров, по проектам которых строился Томск. Это, впрочем, по словам О. Богдановой, не избавляло архитектуру от «классицистической эклектики» [48, с. 18]. Уже отмечалось, что в конце XIX - начале XX вв. архитектурной деятельностью в городе занималось около девяноста архитекторов и инженеров. Среди них наибольшее число (40) - гражданские инженеры - выпускники Строительного училища (более позднее название - Институт гражданских инженеров). Собственно, архитекторов было двадцать; главным образом, это были выпускники Академии художеств (С.-Петербург) и Московского училища живописи, ваяния и зодчества.

Некоторые исследователи $[49,50]$ обращают внимание на анонимность архитектуры уникальных томских слобод с доминирующим массивом деревянных «теремов»; иных исторических зон, с их комплексами, скверами и парками, фрагментами характерного природного ландшафта; городского ядра с главными площадями (лицом сибирского города). Это та анонимность, которая играла и играет особую роль в сложении художественного облика, в формировании особой антропологии города. 
Мы выделили позицию исследователей, которые интерпретируют лишь несколько аспектов развития города (с акцентом на архитектурно-историческом измерении), которые выявляют различный характер складывающейся антропологии [42].

Антропология городской повседневности Томска - это процесс бесконечно открытый и далёкий от завершения. Можно только предположить, что в осознании общности мировосприятия горожан решающую роль играет архитектура [51]. По мнению ряда исследователей, архитектура Томска принципиально антиспектакулярна. Самое сильное ощущение, переживаемое теми, кто живёт здесь постоянно, - отсутствие грандиозного архитектурного замысла, «несделанность» архитектуры, естественность. Изначально планировка улиц в Томске шла в соответствии с рельефом местности, параллельно рекам и оврагам. Этот живой и органичный принцип дорегулярной застройки сохранился в Томске до конца XVIII столетия и, как ни странно, определил архитектурное своеобразие города надолго.

Видение при помощи «разума», «пристальное чтение» для нас выделяет лишь несколько архитектурных форм и пространств, которые обладают «спектакулярностью поневоле» - Воскресенская гора и исторический район Болота, Католический храм Пресвятой Богородицы Святого Розария, Каменный мост через Ушайку. Но это такая архитектурная спектакулярность, которая только добавляет городу своеобразия и создаёт абсолютно органичный, уже «культурный ландшафт» в отличие от сегодняшних архитектурных жестов (каменное обустройство реки Ушайки).

Эту антиспектакулярность, с одной стороны, и способность к рождению новых смыслов, с другой, удивительно чувствовала художница М.Б. Вериго-Чудновская, вынужденно некоторое время жившая в Томске. Её наброски с изображениями Томска, которые воссоздают образ холмистого рельефа, контуры здания магистрата и пожарной части, предельно упрощенно, условно, но удивительно точно («Амбары над Ушайкой»), могли бы стать визуальной метафорой города. Отдельные символы «Городского пейзажа с телеграфными проводами» делают вполне узнаваемыми Почтамтскую улицу (ныне пр. Ленина), районы деревянной застройки (два варианта «Пейзажа с деревянными домами») [52, с. 110]. А с другой стороны, это ощущение идиллии российской провинции исчезает, как только мы вчитываемся в её стихи, посвящённые «столице снега» (так определяет поэт Томск), в её дневники; вглядываемся в её образы людей, живущих в тревожном городе $20-\mathrm{x}$ гг. XX в. Любая часть городского пространства, воссозданная автором, семиотически насыщенна, но, чтобы её декодировать, необходимо иметь некие «горизонты ожидания», которые, вольно или невольно, существуют, задают рамки еще одной моделирующей системы внутри человека, системы геопространственного воображения. Способность этого пространства к генерации новых смыслов, закодированных в архитектуре, до сих пор недооценена.

И еще, не здание, не строение, а канон пустотности, в котором явно вычитывается код города, пустотности, которую истинные архитекторы чувствуют и которая становится способом манифестации пространственной «томскости», не сводимой к экзотической сибирскости, суровости, просторам, удалённости. Если это пространство не считывается адекватно, возникают точечные строения-монстры, разрушающие архитектурную уникальность и сложившуюся «хореографию повседневности». Другое пространство, проявляющее себя и привлекающее взгляд, - пространство в городе, которое противится любой застройке (бывшая территория Томского ипподрома), не имеющее сегодня какихлибо пределов и локализаций, вещей и событий, но притягивающее своей глубиной, объёмностью, эффектом широты. Это пространство явно требует не только позиции наблюдателя в эстетической рефлексии. Но как только в этом конкретном месте мы наблюдаем 
неадекватную архитектурную интервенцию (например, постройка бассейна, существовавшего на месте «Красного факела»), сразу же с уверенностью можно констатировать: судьба этого здания решена, рано или поздно оно будет разрушено, снесено, заброшенно. История таких парадоксально-устроенных пространств свидетельствует: в любом освоенном пространстве, в которое человек неизбежно втягивается, возникает взаимодействие сил. Человек формирует пространство, но и оно «производит» человека. А сегодня провокативные «арт-эксперименты обречены скорее раскалывать сообщества, нежели их консолидировать» [53].

\section{Выводы}

Таким образом, если в городе осуществляется интенсивное проектирование на основе полноценного анализа сложившихся принципов пространственной организации города, то это приводит и к росту исследований, методология которых связана с традициями сложившихся семиотических школ. Они формируют множество «разнокалиберных линз, наведенных на город» и благодаря сборке образов города возникает либо целостный образ города, хранящий дух подлинной жизни, либо фрагментированный, представляющий «город в осколках». Междисциплинарные городские исследования, интенсификация которых связана часто с попытками трансформировать город, также создают объёмные описания культурного ландшафта города, где структурообразующим будет образ, не противоречащий сложившейся системе городского семиозиса. Другое дело, что такой образ в условиях мультиконтектуальности помещается в разные контексты, но всякий раз это должна быть реконструкция проживаемого, «наполненного», сложного пространства, которое противостоит пространству «пустому», географическому.

Исследование выполнено в рамках Программы повышения конкурентоспособности ТПУ и проекта «Европейские практики совместного создания человеко-ориентированных умных городов/Соcreation of EU Human Smart Cities» (Сокращенное название: СоHиSC, проект при поддержке программы Европейского Союза Erasmus+Jean Monnet, номер проекта 600426-EPP-1-2018-1-RU-EPPJMO-PROJECT). Содержание данной публикации отражает только точку зрения авторов, Европейская комиссия не несет ответственность за использование содержащейся в ней информации.

\section{СПИСОК ЛИТЕРАТУРЫ}

1. Creativity, innovation and smartness in destination branding / L. Trinchini, N. Kolodii, N. Goncharova, R. Baggio // International Journal of Tourism Cities. - 2019. - V. 5. - Iss. 2. - P. 529-543.

2. Amin A., Thrift N. Seeing like a city. - Cambridge: Polity Press, 2017. - 203 p.

3. Трубина Е. Полис и мегасобытия // Отечественные записки. - 2012. - № 3 (48). URL: https://stranaoz.ru/2012/3/polis-i-megasobytiya (дата обращения 20.12.2020).

4. Ермолаева П. Социально-экологические барьеры при подготовке городов постсоветской России к спортивному мегасобытию (на примере Универсиады 2013 в Казани) // Журнал социологии и социальной антропологии. $\quad-2013 . \quad-\quad$ T. $16 . \quad-\quad$ № $5 . \quad$ URL: http://www.jourssa.ru/sites/all/files/volumes/2013_5/Ermolayeva_2013_5.pdf ～(дата обращения: 20.12.2020).

5. Самутина Н. Собиратели взгляда // Социологическое обозрение. - 2018. - Т. 17. - № 1. - С. $325-332$.

6. Устюгова Е. Антропологический поворот в современной урбанистике // Terra Aesteticae. Теоретический журнал Российского эстетического общества. - 2018. - № 1 (1). - С. 199-215.

7. Голубев М. Город «большого университета» // Эксперт-Сибирь, 28 июля 2019 г. URL: https://expert.ru/siberia/2019/30/gorod-bolshogo-universiteta/ (дата обращения 03.08.2019).

8. Avni N., Alfasi N. UniverCity: the vicious cycle of studentification in a peripheral city // City \& Community. - 2018. - V. 17. - Iss. 4. - P. 1248-1269.

9. Soja Ed.W. Postmetropolis: critical studies of cities and regions. - Oxford: Wiley-Blackwell, 2000. - 462 p.

10. Аванесов С.С. Сакральная топика русского города // ПРАЕНМА. Проблемы визуальной семиотики. 2016. - № 1 (7). - С. 71-114.

11. Аймермахер К. Знак. Текст. Культура. - М.: РГГУ, 2001. - 394 с. 
12. Арнхейм Р. Искусство и визуальное восприятие - М.: Изд-во «Прогресс», 1974. - 384 с.

13. Барт Р. Избранные работы: Семиотика: Поэтика - М.: Прогресс, 1989. - 616 с.

14. Certeau M. The practice of everyday life. - Berkeley: University of California Press, 1988. - $254 \mathrm{p}$.

15. Ellard C. Places of the heart. The psychogeography of everyday life. - NY: Bellevue Literary Press, 2015. $256 \mathrm{p}$.

16. Frisby D. The metropolis as text. Otto Wagner and Vienna's «Second Renaissance» // The Hieroglyphics of Space. Reading and Expereincing the Modern Metropolis / Ed. by N. Leach. - London: Routledge, 2002. P. 225-239.

17. Лотман Ю.М. Семиосфера // Внутри мыслящих миров. Человек-текст-семиосфера-история. - СПб.: Искусство-СПБ, 2000. - С. 149-390.

18. Палласмаа Ю. Мыслящая рука: архитектура и экзистенциальная мудрость бытия. - М.: Классика-XXI, 2013. - $176 \mathrm{c}$.

19. Турома С. Семиотика городского пространства Ю.М. Лотмана: опыт переосмысления // Новое литературное обозрение. - 2009. - № 4 (98). - С. 66-76.

20. Элкинс Дж. Исследуя визуальный мир. - Вильнюс: ЕГУ, 2010. - 534 с.

21. Kattago S. Encountering the past within the present: modern experiences of time. - N.Y.: Routledge, 2020. $166 \mathrm{p}$.

22. Rethinking historical time: new approaches to presentism / Eds. L. Olivier, M. Tamm. - London, N.Y.: Bloomsbury Academic, 2019. - 226 p.

23. Language, space and power: reflections on linguistic and spatial turns in urban research / J. Vuolteenaho, L. Ameel, A. Newby, M. Scott // Language, Space and Power: Urban Entanglements. - 2012. - P. 1-27. URL: https://www.researchgate.net/publication/301291732_Language_Space_Power_Reflections_on_Linguistic_an d_Spatial_Turns_in_Urban_Research (дата обращения 20.12.2020).

24. Waldstein M. Soviet empire of signs: a history of the Tartu School of Semiotics. - Saarbrücken: VDM Verlag, 2008. $-236 \mathrm{p}$.

25. Линч К. Образ города. - М.: Стройиздат, 1982. - 328 с.

26. Фуко М. Слова и вещи: археология гуманитарных наук - М.: Прогресс, 1977. - 488 с.

27. Kupovykh M. Russifying Estonia? Jurii Lotman and the Politics of Language and Culture in Soviet Estonia // Kritika. - 2007. - V. 8. - № 3. - P. 561-596.

28. Steiner W. Pictorial narrativity // Narrative across Media: the languages of storytelling / Ed. by M.-L. Ryan. Nebraska: University of Nebraska Press, 2004. - P. 145-177.

29. Barrado-Timón D. The meaning and content of the concept of the social in the scientific discourse on urban social sustainability // City \& Community. - 2020. - V. 19. - Iss. 4. - P. 1103-1121.

30. Kress G., Van Leeuwen Th. Reading images: the grammar of visual design. - N.Y.: Routledge, 2001. - 321 p.

31. Schönle A. Lotman and cultural studies. - Madison: University of Wisconsin Press, 2006. - 383 p.

32. Lefebvre H. The production of space. - Cambridge: Cambridge Center, 1984. - 234 p.

33. Лотман Ю.М. Символика Петербурга и проблемы семиотики города // Семиотика города и городской культуры. Ученые записки Тартусского государственного университета. Труды по знаковым системам / под ред. А.Э. Мальц. - Тарту: Изд-во Тартусского ун-та, 1984. - Вып. 664. - С. 30-45.

34. Вольская Л.Н., Беляева Е.К. Среда крупного исторического города в Сибири и её особенности // Творчество и современность. - 2018. - № 4 (8). - С. 5-13.

35. Хворенков Е., Фаткулина Е. Живая лаборатория в Томске: каким будет Smart City, что делать с транспортом и другие идеи горожан. URL: https://obzor.city/article/553692---zhivaja-laboratorija-v-tomskekakim-budet-smartcity-chto-delat-s-transportom-i-drugie-idei-gorozhan (дата обращения 20.12.2020).

36. Смирнов С.А. Образ города: от карты к картоиду // ПРАЕНМА. Проблемы визуальной семиотики. 2017. - № 4 (14). - С. 28-48.

37. Воронина О.С. История градостроительного развития города Томска в XVII-XX вв. // Вестник Томского государственного архитектурно-строительного университета. - 2016. - № 1. - С. 91-106.

38. Бокова М. Беспризорное зодчество Томска. Спор о «списке-701» уводит томичей от главного. URL: https://news.vtomske.ru/view/147690-besprizornoe-zodchestvo-tomska (дата обращения 05.07. 2019).

39. Лефевр А. Производство пространства - М.: Strelka Press, 2015. - 432 c.

40. Айзенман П., Колхас Р. Суперкритика. - М.: Strelka Press, 2017. - 218 c.

41. М. де. Серто. По городу пешком // Социологическое обозрение. - 2000. - Т. 7. - № 2. - С. 24-38.

42. Романова Л.С. Творчество архитектора Константина Лыгина в Томске: (по материалам фонда К.К. Лыгина в Томском областном краеведческом музее). - Томск: Д-Принт, 2004. - 193 с.

43. Асс Е. Гипноз пустого листа. URL: http://www.archplatforma.ru/?act=2\&tgid=665\&stchng=2 (дата обращения 04.05.2019). 
44. Дмитриенко Н.М. Томск от А до Я: краткая энциклопедия города. - Томск: Издательство научно-технической литературы, 2004. - 438 с.

45. Залесова П.В., Манонина Т.Н. Творческая деятельность архитекторов немецкого происхождения в Сибири (конец ХІХ - начало ХХ в.) // Вестник ТГАСУ. - 2015. - № 1. - С. 44-51.

46. Ревзин Г.И. Очерки по философии архитектурной формы - М.: ОГИ, 2002. - 138 с.

47. Болтовская И.Ю., Прислонова Д.В. Роль купеческих династий в создании архитектурного облика сибирских городов на примере Кухтериных в Томске и Гадаловых в Красноярске // Сибирское купечество: истоки, деятельность, наследие: материалы Третьей Всероссийской научной конференции. Томск, 21-23 сентября 2018. - Томск: Изд-во Том. гос. архит.-строит. ун-та, 2019. - С. 49-53.

48. Богданова О.В. Архитектурный облик Томска. - Томск: Красное знамя, 2005. - 143 с.

49. Бойко В.П., Ситникова Е.В. Сибирское купечество и формирование архитектурного облика города Томска в ХІХ - начале ХХ в. - Томск: Изд-во ТГАСУ, 2008. - 179 с.

50. Емельянов Е.Ю., Ситникова Е.В. Графическая реконструкция доходного дома врача А.И. Макушина на ул. Октябрьской, 4 в г. Томске // Творчество и современность. - 2018. - № 1 (5). - С. 34-38.

51. Baggio R., Moretti V. Beauty as a factor of economic and social development // Tourism Review. - 2018. V. 73. -№ 1. - P. 68-81.

52. Микуцкая Т.П. Художник поколения 1890-х гг. М.Б. Вериго: биография и творчество // История и культура Томской области / под ред. Я. Яковлева, Л. Овчинниковой. - Томск, Изд-во Томского университета, 1998. - С. 108-115.

53. Трубина Е. Город: стратегии и тактики // Художественный журнал. - 2013. - № 8. URL: http://moscowartmagazine.com/issue/8/article/86 (дата обращения 23.06.2019)

Дата поступления: 23.01.2021 г. 
UDC 101.1:316.334.56(47+57)

\title{
SEMIOTIC INVENTORY OF THE CITY AND THE PROBLEM OF INTENSIVE SPATIAL DEVELOPMENT
}

\author{
Nataliia A. Kolodii', \\ kolna@tpu.ru \\ Baggio Rodolfo', \\ rodolfo.baggio@unibocconi.it \\ Natalia A. Goncharova ${ }^{1}$, \\ natg@tpu.ru \\ Yuliya A. Chayka ${ }^{1}$, \\ chayka@tpu.ru \\ Vera S. Ivanova ${ }^{2}$, \\ vcsoc@rambler.ru \\ ${ }^{1}$ National Research Tomsk Polytechnic University, \\ 30, Lenin avenue, Tomsk, 634050, Russia \\ 2 National Research Tomsk State University, \\ 36, Lenin avenue, Tomsk, 634050, Russia
}

Nataliia A. Kolodii, Dr. Sc., professor, National Research Tomsk Polytechnic University.

Baggio Rodolfo, PhD, professor, National Research Tomsk Polytechnic University.

Natalia A. Goncharova, Cand. Sc., associate professor, National Research Tomsk Polytechnic University.

Yuliya A. Chayka, senior lecturer, National Research Tomsk Polytechnic University.

Vera S. Ivanova, Cand. Sc., associate professor, National Research Tomsk State University.

The influence that modern citizens have on the cities' spatial development forces city planners as well as those implementing various urban projects to pay attention to the languages describing the city, which create a dominant image of a unique space and territory. This engagement can contribute to harmonious and sustainable spatial development, but it may also hinder the implementation of any urban project. The article devoted to the analysis of the city description languages considers a number of problems associated with the understanding under what conditions the city description languages contribute to the formation of the city's identity and its authentic spatial development, under what conditions they create ambiguous contradictory images. The methodological basis of the article is the structural-semiotic approach, as it builds a system for analyzing the city as a text and the city as a text-generating mechanism, a meaning-creating system. Also the concept of urban imaginary has been used as a conceptual reference point (A. Blum, K. Lynch, M. de Certeau), which made it possible to perceive the urban imaginary as a product of perception of urban reality, designed in the form of various interpretive schemes and texts. Semiotic inventory, related to the spatial system of the modern city, is necessary to understand the following: how the new symbolic order of the city and its new symbolic universe will be «produced». The research results presented in the article are based on mental maps analysis and digital phenomena which made it possible to recreate the contours of the visual image of the Siberian city (as a holistic formation) with a certain system of meanings coding. Interdisciplinary urban studies, the intensification of which is often associated with attempts to transform the city, create voluminous descriptions of the cultural landscape of the city, where the structure-forming image will be that does not contradict the existing system of urban semiosis. 
Key words: Urban text, local text, visual research, semiotic approach, culturally determined design, language of city description.

The research was carried out within the framework of the TPU Competitiveness Enhancement Program and the project "Co-creation of EU Human Smart Cities» (that stands for the abbreviation CoHuSC, the project supported by the European Union program Erasmus + Jean Monnet, project number 600426-EPP-1-2018-1-RUEPPJMO-PROJECT). The content of this publication reflects only the views of the authors, the European Commission is not responsible for the use of the information contained therein.

\section{REFERENCES}

1. Trinchini L., Kolodii N., Goncharova N., Baggio R. Creativity, innovation and smartness in destination branding. International Journal of Tourism Cities, 2019, vol. 5, Iss. 2, pp. 529-543.

2. Amin A., Thrift N. Seeing like a city. Cambridge, Polity Press, 2017. 203 p.

3. Trubina E. Polis i megasobytiya [Policy and mega-events]. Otechestvennye zapiski, 2012, no. 3 (48). Available at: https://strana-oz.ru/2012/3/polis-i-megasobytiya (accessed 20 December 2020).

4. Ermolaeva P. Socialno-ekologicheskie barery pri podgotovke gorodov postsovetskoy Rossii k sportivnomu megasobytiyu (na primere Universiady $2013 \mathrm{v}$ Kazani) [Socio-ecological barriers in preparing the cities of post-Soviet Russia for the sports mega-event (on the example of the 2013 Universiade in Kazan)]. Zhurnal sotsiologii $i$ sotsialnoy antropologii, 2013, vol. 16, no. 5. Available at: http://www. jourssa.ru/sites/all/files/volumes/2013_5/Ermolayeva_2013_5.pdf (accessed: 20 December 2020).

5. Samutina N. Sobirateli vzglyada [Focusing the gaze]. Sociologicheskoe obozrenie, 2018, vol. 17, no. 1, pp. 325-332.

6. Ustyugova E. Antropologicheskiy povorot v sovremennoy urbanistike [Anthropological turn in contemporary urbanistics]. Terra Aesteticae. Teoreticheskiy zhurnal Rossiyskogo esteticheskogo obshchestva, 2018, no. 1 (1), pp. 199-215.

7. Golubev M. Gorod «bolshogo universiteta». Ekspert-Sibir, 2019. Available at: https://expert.ru/siberia/2019/30/gorod-bolshogo-universiteta/ (accessed 3 August 2019).

8. Avni N., Alfasi N. UniverCity: the vicious cycle of studentification in a peripheral city. City \& Community, 2018, vol. 17, Iss. 4, pp. 1248-1269.

9. Soja Ed.W. Postmetropolis: critical studies of cities and regions. Oxford, Wiley-Blackwell, 2000. 462 p.

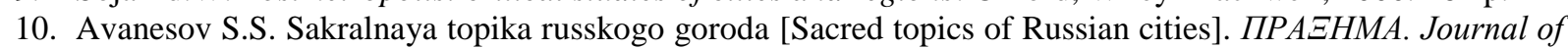
Visual Semiotics, 2016, no. 1 (7), pp. 71-114.

11. Aymermakher K. Znak. Tekst. Kultura [Sign. Text. Culture]. Moscow, RGGU Publ., 2001. 394 p.

12. Arnkheym R. Iskusstvo i vizualnoe vospriyatie [Art and visual perception]. Moscow, Progress Publ., 1974. $384 \mathrm{p}$.

13. Bart R. Izbrannye raboty: Semiotika: Poetika [Selected works: Semiotics: Poetics]. Moscow, Progress Publ., 1989. $616 \mathrm{p}$.

14. Certeau M. The practice of everyday life. Berkeley, University of California Press, 1988. 254 p.

15. Ellard C. Places of the heart. The psychogeography of everyday life. NY, Bellevue Literary Press, 2015. 256 p.

16. Frisby D. The metropolis as text. Otto Wagner and Vienna's «Second Renaissance». The Hieroglyphics of Space. Reading and Expereincing the Modern Metropolis. Ed. by N. Leach. London, Routledge, 2002. pp. $225-239$.

17. Lotman Ju.M. Semiosfera [Semiosphere]. Vnutri myslyashchikh mirov. Chelovek-tekst-semiosfera-istoriya [Inside thinking worlds. Human-text-semiosphere-history]. St-Petersburg, Iskusstvo Publ., 2000. pp. 149-390.

18. Pallasmaa Yu. Myslyashchaya ruka: arkhitektura i ekzistentsialnaya mudrost bytiya [Thinking hand: architecture and existential wisdom of being]. Moscow, Klassika-XXI Publ., 2013. 176 p.

19. Turoma S. Semiotika gorodskogo prostranstva Yu.M. Lotmana: opyt pereosmysleniya [Semiotics of urban space of Yu.M. Lotman: an experience of rethinking]. Novoe literaturnoe obozrenie, 2009, no. 4 (98), pp. 6676.

20. Elkins J. Issleduya vizualnyy mir [Exploring the visual world]. Vilnius, EGU Publ., 2010. 534 p.

21. Kattago S. Encountering the past within the present: modern experiences of time. N.Y., Routledge, 2020. 166 p.

22. Rethinking historical time: new approaches to presentism. Eds. L. Olivier, M. Tamm. London, N.Y., Bloomsbury Academic, 2019. 226 p. 
23. Vuolteenaho J., Ameel L., Newby A., Scott M. Language, space and power: reflections on linguistic and spatial turns in urban research. Language, Space and Power: Urban Entanglements, 2012, pp. 1-27. Available at: https://www.researchgate.net/publication/301291732_Language_Space_Power_Reflections_on_Linguistic_and_Spatial_Turns_in_Urban_Research (accessed 20 December 2020).

24. Waldstein M. Soviet empire of signs: a history of the Tartu School of Semiotics. Saarbrücken, VDM Verlag, 2008. 236 p.

25. Linch K. Obraz goroda [The image of the city]. Moscow, Stroiizdat Publ., 1982. 328 p.

26. Fuko M. Slova i veshchi: arkheologiya gumanitarnykh nauk [Words and things: archeology of the humanities]. Moscow, Progress Publ., 1977. 488 p.

27. Kupovykh M. Russifying Estonia? Jurii Lotman and the politics of language and culture in Soviet Estonia. Kritika, 2007, vol. 8, no. 3, pp. 561-596.

28. Steiner W. Pictorial narrativity. Narrative across Media: the languages of storytelling. Ed. by M.-L. Ryan. Nebraska, University of Nebraska Press, 2004. pp. 145-177.

29. Barrado-Timón D. The meaning and content of the concept of the social in the scientific discourse on urban social sustainability. City \& Community, 2020, vol. 19, Iss. 4, pp. 1103-1121.

30. Kress G., Van Leeuwen Th. Reading images: the grammar of visual design. N.Y., Routledge, 2001. $321 \mathrm{p}$.

31. Schönle A. Lotman and Cultural Studies. Madison, University of Wisconsin Press, 2006. 383 p.

32. Lefebvre H. The production of space. Cambridge, Cambridge Center, 1984. 234 p.

33. Lotman Yu.M. Simvolika Peterburga i problemy semiotiki goroda [The symbolism of St. Petersburg and the problems of the semiotics of the city]. Semiotika goroda i gorodskoy kultury. Uchenye zapiski Tartusskogo gosudarstvennogo universiteta. Trudy po znakovym sistemam [Semiotics of the city and urban culture. Tartu State University Scholarly Notes. Transactions on sign systems]. Ed. by A.E. Maltz. Tartu, Publ. Tartusskogo gosudarstvennogo universiteta, 1984. Iss. 664, pp. 30-45.

34. Volskaya L.N., Belyaeva E.K. Sreda krupnogo istoricheskogo goroda v Sibiri i ee osobennosti [The environment of a large historical city in Siberia and its features]. Tvorchestvo i sovremennost, 2018, no. 4 (8), pp. 513.

35. Khvorenkov E., Fatkulina E. Zhivaya laboratoriya v Tomske: kakim budet Smart City, chto delat $s$ transportom i drugie idei gorozhan [Living laboratory in Tomsk: what Smart City will look like, what to do with transport and other ideas of citizens]. Available at: https://obzor.city/article/553692---zhivaja-laboratorija-v-tomske-kakim-budet-smartcity-chto-delat-s-transportom-i-drugie-idei-gorozhan (accessed 20 December 2020).

36. Smirnov S.A. Obraz goroda: ot karty k kartoidu [Image of the city: from map to cartoid]. ПPA $\Xi$ MA. Journal of Visual Semiotics, 2017, no. 4 (14), pp. 28-48.

37. Voronina O.S. Istoriya gradostroitelnogo razvitiya goroda Tomska v XVII-XX vv. [The history of the urban development of the city of Tomsk in XVII-XX centuries]. Vestnik Tomskogo gosudarstvennogo arhitekturnostroitelnogo universiteta, 2016, no. 1, pp. 91-106.

38. Bokova M. Besprizornoe zodchestvo Tomska. Spor o «spiske-701» uvodit tomichey ot glavnogo [Homeless architecture of Tomsk. The dispute about the «701 list» takes Tomsk citizens away from the main thing]. Available at: https://news.vtomske.ru/view/147690-besprizornoe-zodchestvo-tomska (accessed 5 July 2019).

39. Lefevr A. Proizvodstvo prostranstva [The production of space]. Moscow, Strelka Press, 2015. 432 p.

40. Aizenman P., Kolhas R. Superkritika [Supercritic]. Moscow, Strelka Press, 2017. 218 p.

41. M. de. Serto. Po gorodu peshkom [Walk around the city]. Sotsiologicheskoe obozrenie, 2000, vol. 7, no. 2, pp. 24-38.

42. Romanova L.S. Tvorchestvo arkhitektora Konstantina Lygina v Tomske: (po materialam fonda K.K. Lygina $v$ Tomskom oblastnom kraevedcheskom muzee) [The work of the architect Konstantin Lygin in Tomsk: (based on the materials of the K.K. Lygin foundation in the Tomsk Regional Museum of Local Lore)]. Tomsk, DPrint, 2004. 193 p.

43. Ass E. Gipnoz pustogo lista [Blank slate hypnosis]. Available at: http://www. archplatforma.ru/?act=2\&tgid=665\&stchng=2 (accessed 4 May 2019)

44. Dmitrienko N.M. Tomsk ot A do Ya: kratkaya entsiklopediya goroda [Tomsk from A to Z: a brief encyclopedia of the city]. Tomsk, Scientific and technical literature Publ., 2004. 438 p.

45. Zalesova P.V., Manonina T.N. Tvorcheskaya deyatelnost arkhitektorov nemetskogo proiskhozhdeniya $\mathrm{v}$ Sibiri (konets XIX - nachalo XX v.) [Creative activity of architects of German origin in Siberia (late XIX early XX century)]. Vestnik TGASU, 2015, no. 1, pp. 44-51.

46. Revzin G.I. Ocherki po filosofii arkhitekturnoy formy [Essays on the philosophy of architectural form]. Moscow, OGI Publ., 2002. 138 p.

47. Boltovskaya I.Yu., Prislonova D.V. Rol kupecheskikh dinastiy v sozdanii arkhitekturnogo oblika sibirskikh gorodov na primere Kukhterinykh v Tomske i Gadalovykh v Krasnoyarske [The role of merchant dynasties 
in creating the architectural appearance of Siberian cities on the example of the Kukhterins in Tomsk and the Gadalovs in Krasnoyarsk]. Sibirskoe kupechestvo: istoki, deyatelnost, nasledie: materialy Tretey Vserossiyskoy nauchnoy konferentsii [Siberian merchants: origins, activities, heritage: materials of the Third AllRussian scientific conference]. Tomsk, 21-23 September 2018. Tomsk, Tomsk State Architecture and Building University Press, 2019. pp. 49-53.

48. Bogdanova O.V. Arhitekturny oblik Tomska [The architectural appearance of Tomsk]. Tomsk, Krasnoe znamya Publ., 2005. 143 p.

49. Boyko V.P., Sitnikova E.V. Sibirskoe kupechestvo i formirovanie arkhitekturnogo oblika goroda Tomska $v$ $X I X$ - nachale $X X v$. [Siberian merchants and the formation of the architectural appearance of the city of Tomsk in the 19th - early 20th centuries]. Tomsk, TGASU Publ., 2008. $179 \mathrm{p}$.

50. Emelyanov E.Yu., Sitnikova E.V. Graficheskaya rekonstruktsiya dokhodnogo doma vracha A.I. Makushina na ul. Oktyabrskoy, $4 \mathrm{v}$ g. Tomske [Graphic reconstruction of the apartment house of the doctor A.I. Makushin on the street October, 4 in Tomsk]. Tvorchestvo i sovremennost, 2018, no. 1 (5), pp. 34-38.

51. Baggio R., Moretti V. Beauty as a factor of economic and social development. Tourism Review, 2018, vol. 73, no. 1, pp. 68-81.

52. Mikutskaya T.P. Khudozhnik pokoleniya 1890-h gg. M.B. Verigo: biografiya i tvorchestvo [Artist of the 1890s generation M.B. Verigo: biography and creativity]. Istoriya i kultura Tomskoy oblasti [History and culture of the Tomsk region]. Eds. Ya. Yakovlev, L. Ovchinnikova. Tomsk, TSU Publ., 1998. pp. 108-115.

53. Trubina E. Gorod: strategii i taktiki [City: strategies and tactics]. Khudozhestvenny zhurnal, 2013, no. 8. Available at: http://moscowartmagazine.com/issue/8/article/86 (accessed 23 June 2019).

Received: 23 January 2021. 